\title{
Azonnali implantáció és lágyrészformázás saját foggal kombinált ideiglenes PMMA felépítménnyel
}

\author{
Esetismertetés
}

DR. BERKEI GÁBOR*, DR. LUKÁCS LÁSZLÓ*, DR. VÁG JÁNOS**

\begin{abstract}
Manapság az implantológia fejlődésével lehetővé vált, hogy fogeltávolítást követő azonnali implantátum beültetés esetén megőrizzük az eredeti lágyrész viszonyokat, ezzel megteremtve egy esztétikus és hosszútávon funkcionáló pótlás elkészítésének lehetőségét. Fontos lépés az azonnali implantációt követően a lágyrészek formázásához, megőrzéséhez az ideiglenes pótlás készítése. Egyszerű és hatékony megoldás lehet gyári PMMA (poli metil-metaklirlát) ideiglenes felépítményt az eltávolított fog koronai részével kombinálni.

Esetbemutatásunkban a balesetben eltört első metszőfoggal jelentkező páciensünknél azonnali implantáció mellett döntöttünk. A papillák és lágyrészviszonyok megőrzése érdekében azonnali ideiglenes koronát készítettünk egy PMMA ideiglenes implantátumfejet és az eltávolított fog koronáját felhasználva. A gyógyulást követően, a végleges pótlás készítésekor egyéni lenyomati fejet használva lemintáztuk a megformázott ínyviszonyokat, majd cirkónium egyéni implantátum felépítményt és e.max préskerámia koronát készítettünk végleges pótlásként.
\end{abstract}

Kulcsszavak: azonnali implantáció, azonnali ideiglenes PMMA, egyéni lenyomati fej, lágyrészformázás, emergencia profil

\section{Bevezetés}

Az implantáció sikerességéhez elengedhetetlen a megfelelő emergencia-profil kialakítása, amely mind az esztétika kialakításában, mind pedig a periimplantáris mukóza megfelelő funkciójában egyaránt fontos [1, 2, 3]. Erre a legmegfelelőbb időpont, ha erre lehetőségünk van, az a fogeltávolítással egy időben elvégzett implantáció és azonnali ideiglenes koronakészítés [4, 5]. Ennek előnye, hogy a páciens egyből ideiglenes pótlással távozhat és megőrizhetjük, illetve tovább alakíthatjuk az eredeti ínyviszonyokat. Ha a gyári körszimmetrikus ínyformázó csavar kerül be először és attól eltérő formát akarunk kialakítani, egyedileg kell meghatároznunk az adott fogtípusra jellemző formát, ehhez szék mellett kell kialakítanunk kész gyári elemek és kompozit vagy akrilát segítségével a leendő emergencia profilt és az ideiglenes pótlást $[6,7,8,9]$. Felmerült bennünk, hogy ha kombinálunk egymással egy PMMA (poli metil-metakrilát) ideiglenes implantátum felépítményt (VITA CADTemp, RC Temporary Abutment, Straumann, Svájc) és az eltávolított fog koronai részét, akkor színben és formában megfelelő ideiglenes koronát tudtunk készíteni. Azt is szem előtt tartottuk, hogy így csökkenthetjük a kompozit és akrilát anyagok monomerjei által kiváltott irritációt, mivel így a nem tökéletesen polimerizált anyagok nem érintkeznek közvetlenül a páciens szubmukozális szöveteivel $[10,11]$. Ezt az elvet követve kezeltük az esetismertetés alanyát és arra voltunk kíváncsiak, hogy el tudjuk-e érni a kívánt esztétikai és funkcionális eredményt.

\section{Esetismertetés}

Az alább ismertetett esetnél kiemelten fontos volt az eredeti esztétikai viszonyok megőrzése. A páciens foglalkozásából adódóan elsődleges volt számára, hogy azonnal ideiglenes pótlással lássuk el, és az, amennyire csak lehetséges, hasonlítson a kezelés során eltávolított fogára. Mivel a fog nem parodontális vagy kariológiai okokból lett eltávolítva, és az anatómiai viszonyok ezt lehetővé tették, azonnali implantáció és azonnali ideiglenes készítés mellett döntöttünk, melyhez az ideiglenes koronát az eltávolított fog koronáját és egy PMMA ideiglenes felépítményt felhasználva készítettünk el.

Harmincas évei elején járó hölgy páciensünk azzal a panasszal érkezett, hogy miután ütés érte bal felső első metszőfogát, az „meglazult” és mozog. A páciens nem dohányzik, általános egészségi állapota jó, szájhigiénéje megfelelő. Már a találkozásunk legelején jelezte, hogy minden kezelés után ideiglenes pótlással szeretne távozni.

A radiológiai vizsgálat alapján $(90 \mathrm{kV}, 8 \mathrm{~mA}, 15,2 \mathrm{sec}$, $150 \mu \mathrm{m}$ pixel, ProMax 3D Max CBCT, Planmeca, Helsinki, Finnország) úgy találtuk, hogy a sérült fog szagittális gyökérpozíciója a Kan szerinti klasszifikáció alap- 


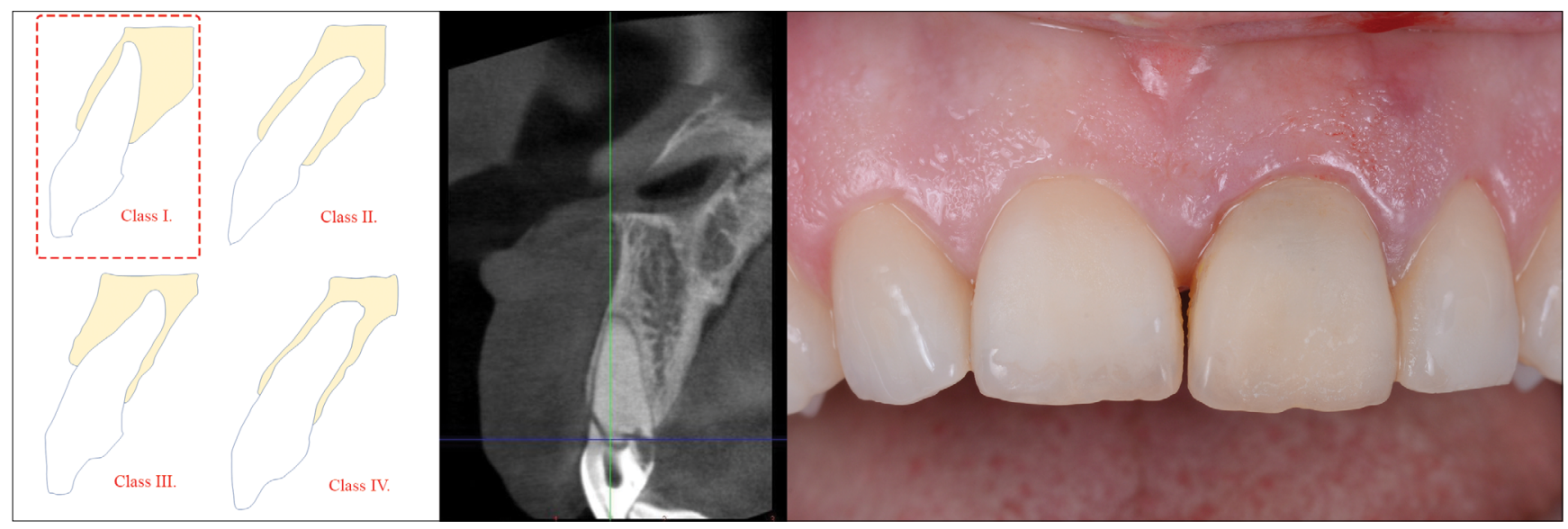

1. kép: Radiológiai és klinikai vizsgálat, kiindulási kép

ján az első csoportba esik [12], a klinikai vizsgálat pedig vastag fenotípust, kedvező ínylefutást, alacsony papillákat, valamit szögletes fogformát mutatott (1. kép). Ezek alapján úgy véltük, esztétikailag egy alacsony kockázatú esettel állunk szemben [13], így a páciens alkalmas a fog atraumatikus eltávolítását követően azonnali implantációra, és megfelelő primer stabilitás esetén előnyös lenne az implantátumra azonnali ideiglenes koronát készíteni.

A műtétet lokális érzéstelenítésben végeztük, a sérült fogat a bukkális csontfal sérülése nélkül eltávolítottuk, majd egy kétfázisú, csavarimplantátum (Bone Level Tapered, SLActive 4,1 × $12 \mathrm{~mm}$, Straumann, Svájc) került beültetésre az alveolus palatinális falán kialakított furatba. Az implantátum teste és a bukkális csontfal közötti résbe xenograft eredetű csontpótló anyagot (cerabone, botiss, Straumann group, Svájc) töltöttünk a koronális csontszintig (2. kép). A posztoperatív időszakban a páciensnek 1 hétig antibiotikumot (Amoxicillin + Klavulánsav, Augmentin Duo 1000 mg $2 \times 1$, SmithKline Beecham Pharmaceuticals, Nagy-Britannia) és fájdalomcsillapítót rendeltünk (Diclofenac, Cataflam 50 mg, Novartis Hungária, Magyarország). A szájhigiéné fenntartására a mútét utáni első naptól puha sörtéjü fogkefével való fogmosást, valamint klórhexidin tartalmú szájvízzel (Curasept ADS implant, 0,2\%, Curaprox, Svájc) történő öblögetést javasoltunk naponta kétszer 1 hétig.

Az implantáció során az implantátumot sebészi motorral hajtottuk be (Implantmed plus, W\&H, Ausztria). A sebészi motor mérése alapján megfelelő primer stabilitást értünk el (40 Ncm), így az azonnali ideiglenes koronakészítést lehetségesnek ítéltük [14]. Az optimális esztétika érdekében a páciens eltávolításra került fogát a mútét során megtartottuk és a koronai részét felhasználtuk az ideiglenes korona elkészítéséhez. Az ideiglenes fejet egy PMMA ideiglenes gyári elemből alakítottuk ki szék mellett. Az anatómiai viszonyoknak megfelelő emergencia profilt a fej befaragásával értük el. Szem előtt tartva az implantátum szagittális helyzetét, az emergencia profil bukkális lefutásához konvex formát faragtunk ki [9]. Az így előkészített ideiglenes fej szupragingivális részét 50 mikronos alumínium-oxid homokfúvással érdesítettük, majd a felület bondozását követően (Optibond FL, Kerr, Németország) folyékony kompozittal (Gradia Flow, GC, Japán) hozzáragasztottuk az eltávolított fog koronai részét (3. kép).

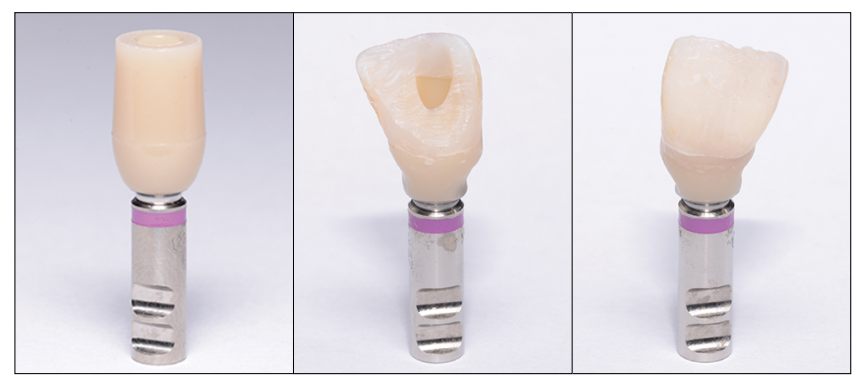

3. kép: PMMA gyári ideiglenes fej és az ebből kialakított felcsavarozható ideiglenes korona

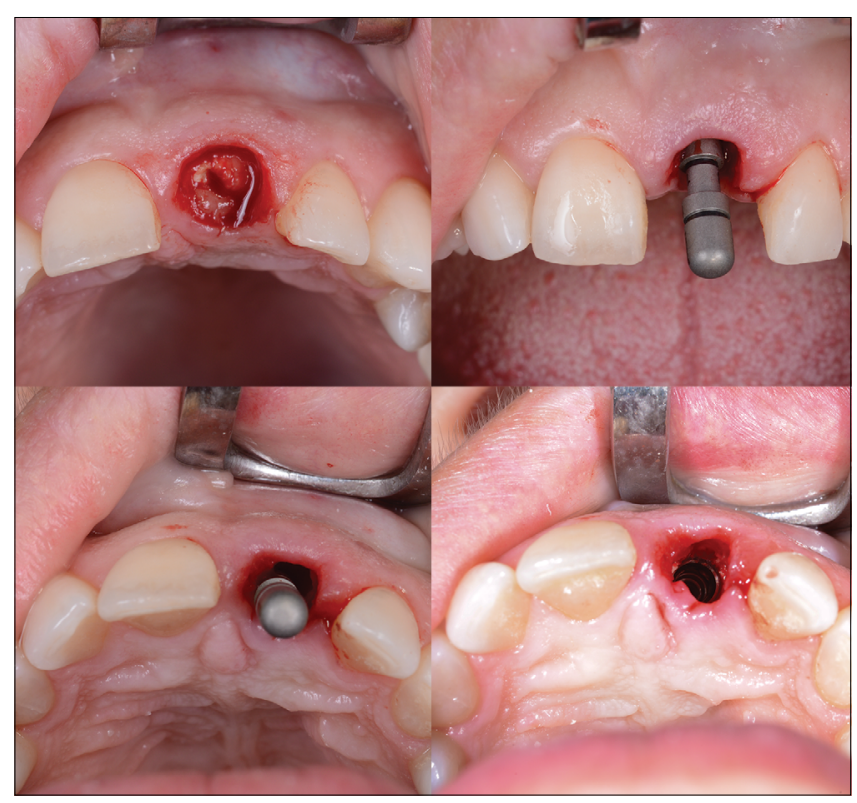

2. kép: Straumann Bone Level Tapered SLActive implantátum behelyezése 


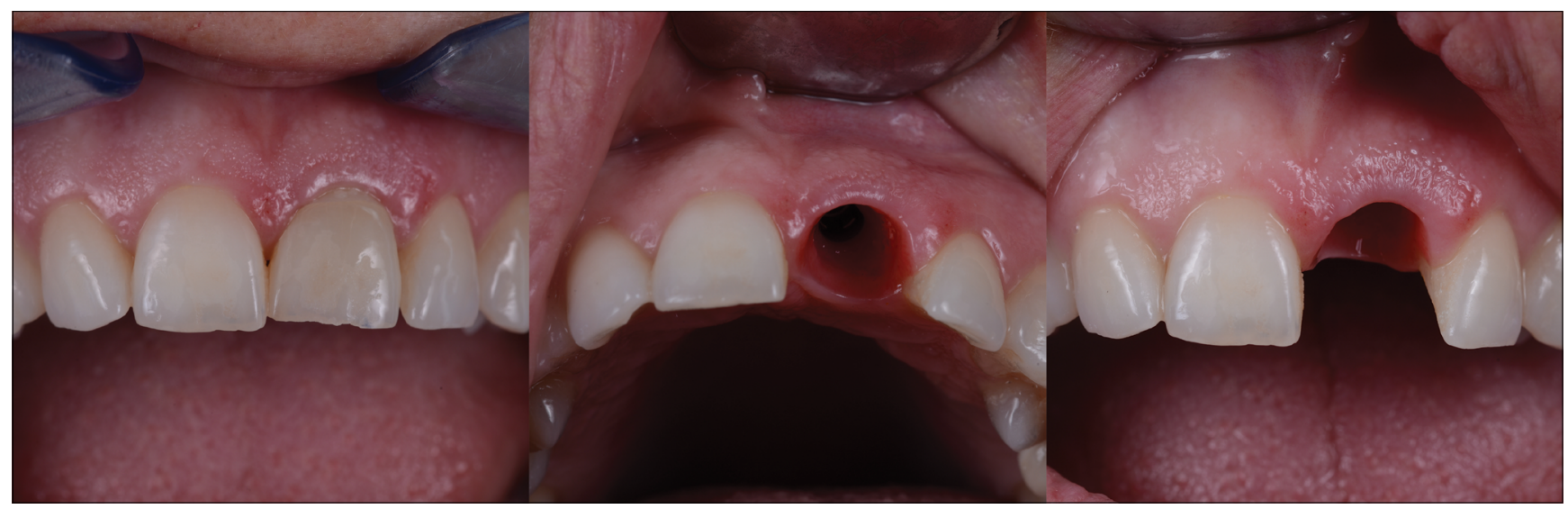

4. kép: Ideiglenes korona az implantációt követően, majd a kialakított ínylefutás 3 hónap elteltével

Az ideiglenes koronát átmenő csavarral rögzítettük $20 \mathrm{Ncm}$ nyomatékkal a behelyezett implantátumra, majd varrat behelyezése nélkül 3 hónapig hagytuk gyógyulni. A gyógyulási idő leteltével, teljesen megtartott papillákat és optimális lágyrész viszonyokat tapasztaltunk (4., 5. kép).

A végleges pótlás elkészítésénél elsődleges szempont volt a kialakított ínyviszonyok megőrzése, így gyári protetikai fej helyett egyéni fej készítése mellett döntöt-

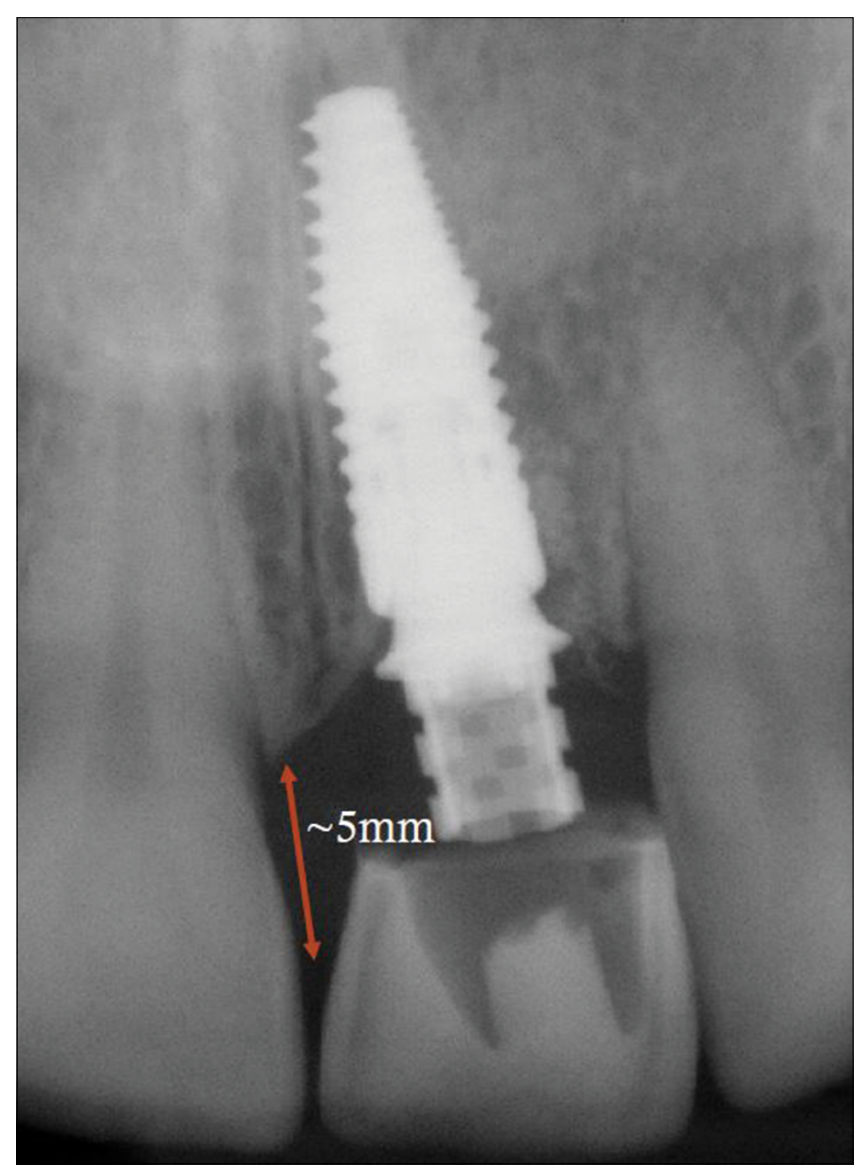

5. kép: Az implantáció utáni kontroll röntgenfelvétel tünk. Az anyagválasztás során azt is szem előtt tartottuk, hogy az hámtapadás kialakulását minél jobban segítsük, valamint a koronai rész is megfeleljen az esztétikai elvárásoknak. Választásunk végül egy titánbázisra ragasztott (Variobase, Straumann, Svájc), CADCAM technológiával faragott cirkon egyéni fejre és egy leplezett préskerámia koronára esett (e.max, Ivoclar Vivadent, Lichtenstein).

Az ideiglenes koronáról szájon kívül lenyomat készült, és ebbe a lenyomatba helyeztük a nyitott kanalas lenyomati fejet (Straumann, Svájc). A körszimmetrikus lenyomatvételi fej és az emergencia profil közötti rést Pattern Resinnel (GC, Japán) töltöttük ki. A resinnel kiegészített lenyomatvételi elemet ezek után szájba helyeztük és nyitott kanalas lenyomatot vettünk egyéni kanállal [15] (6. kép).

Az elkészült cirkon egyéni fejet megfestettük, hogy a transzparens pelletből préselt korona színéhez minél jobban hasonlítson. A megfestett fejet a labor összeragasztotta a gyári titánbázissal (Variobase, Straumann, Svájc). Az egyéni fej próbája során e.max (Ivoclar Vivadent, Lichtenstein) fogszínkulccsal határoztuk meg a szomszédos fog színét, erről hagyományos, valamint keresztpolarizált felvételeket küldtünk a labornak (7. kép).

A páciens kérésére a koronát az eredeti fognál szélesebbre készítettük, ezzel zárva a disztémát. Az elkészült koronát adhezíven rögzítettük az implantátumra helyezett és $35 \mathrm{Ncm}$ nyomatékkal rögzített egyéni cirkonfejre. A ragasztás Variolink Esthetic DC (Ivoclar Vivadent, Lichtenstein) kettős kötésű kompozit cementtel történt, a gyári protokoll alapján. A cirkonfejet Ivoclean tisztító pasztával kezeltük, majd alapos öblítés után a leszárított felszínre Monobond Plus kerámia bondot vittünk fel, a préskerámia koronát Ivoclean pasztával tisztítottuk, majd Monobond Etch and Prime, önsavazó kerámia bonddal kezeltük. Ezután Variolink Esthetic DC kompozit cementtel ragasztottuk, a cementből „neutral” színváltozatot használtunk, mert az elkészült munka színét jónak találtuk és azon nem akartunk változtatni (8. kép). 


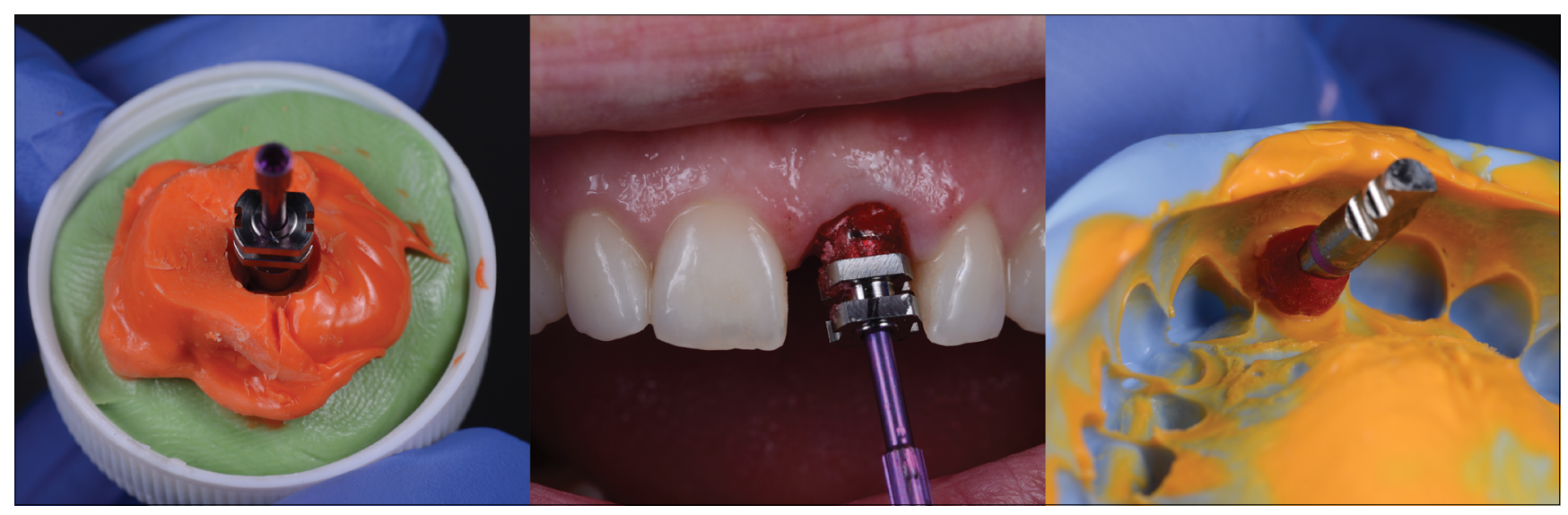

6. kép: Az egyéni nyitottkanalas lenyomati fej készítése és a lenyomat

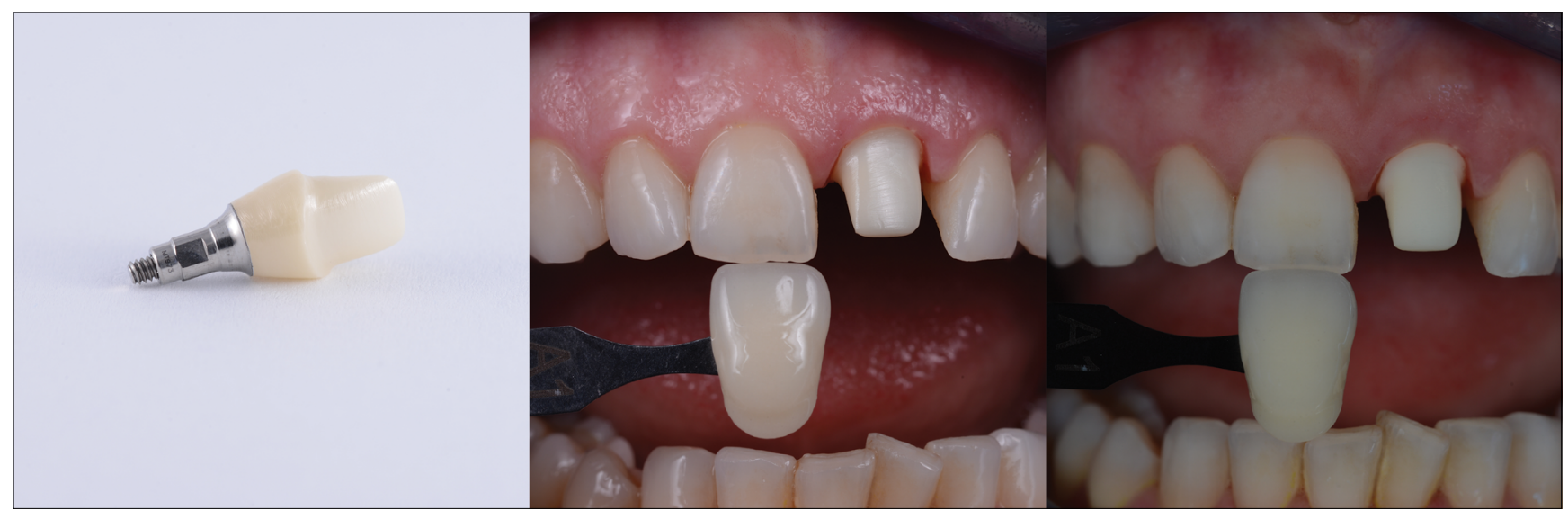

7. kép: Az egyéni cirkonfej próbája és fogszín-meghatározás e.max fogszínkulcs segítségével

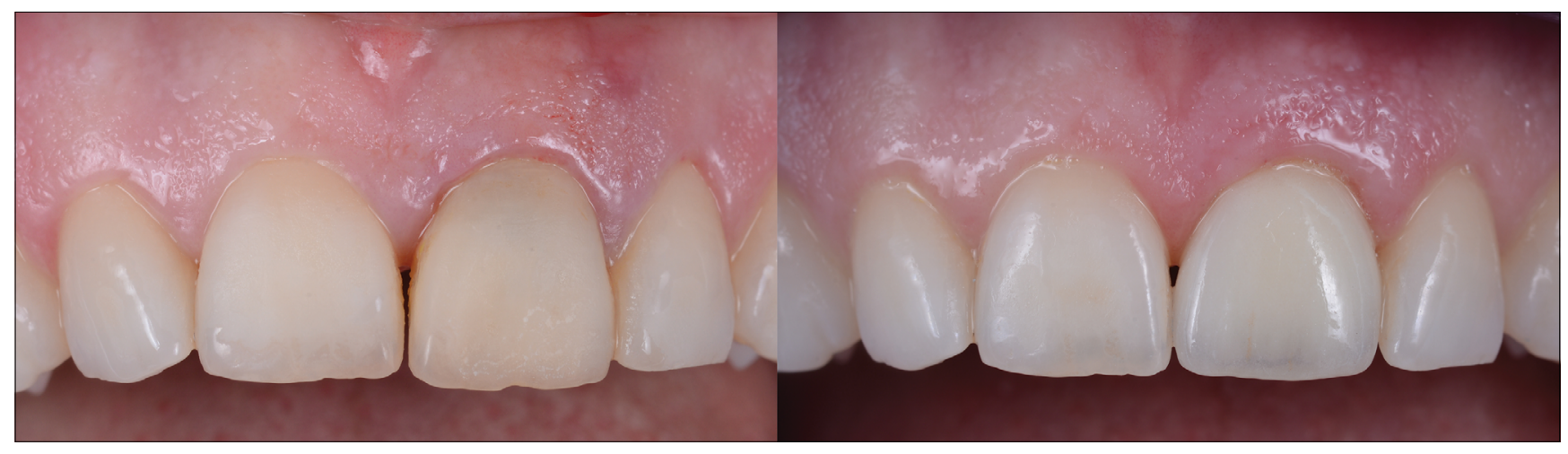

8. kép: Balra a kiindulási állapotról, jobbra az elkészült munkáról készült kép

\section{Konklúzió}

Az elkészült munkával a páciens elégedett volt, az azonnali implantációnak és ideiglenes készítésnek köszönhetően a kezelés során végig esztétikus ideiglenes koronát viselhetett. Az eredeti ínyviszonyokat megőriztük, így egy hosszútávon fenntartható helyzetet teremtettünk (9. kép).
A gyári PMMA ideiglenes fejnek köszönhetően a kezelési idő lerövidült, az allergiás reakció lehetőségét csökkentettük. Azonnali implantációnál ha lehetőség van rá, jó megoldásnak túnik az eltávolított fog koronáját mint ideiglenes koronát felhasználni. A természetes fog koronai része ellenálló, a színét és formáját jobban megőrzi, mint egy akrilát korona. 


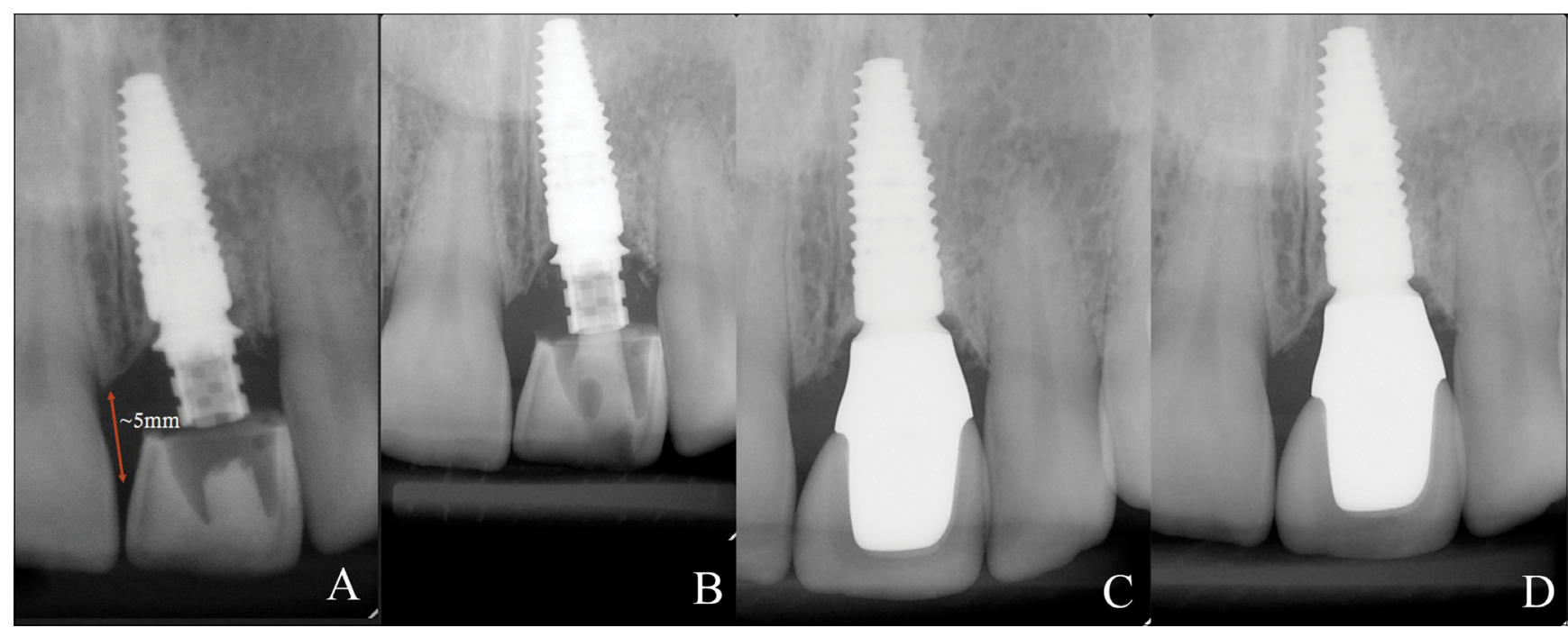

9. kép: A: Az implantáció utáni kontroll röntgenfelvétel, B: 2 hónappal a mútét után, C: 6 hónappal a végleges korona átadása után, D: 2,5 évvel a végleges korona átadása után

\section{Irodalom}

1. Berglundh T, LINDHE J: Dimension of the periimplant mucosa. Biological width revisited. J Clin Periodontol. 1996 Oct; 23 (10): 971973. https://doi.org/10.1111/j.1600-051X.1996.tb00520.x

2. Hermann JS, Buser D, Schenk RK, Higginbottom FL, Cochran DL: Biologic width around titanium implants. A physiologically formed and stable dimension over time. Clin Oral Implants Res. $2000 \mathrm{Feb}$; 11 (1): 1-11. https://doi.org/10.1034/j.1600-0501.2000.011001001.x

3. Smukler H, Castellucci F, Capri D: The role of the implant housing in obtaining aesthetics: generation of peri-implant gingivae and papillae Part 1. Pract Proced Aesthet Dent. 2003 Mar; 15 (2): 141149; quiz 150. Review.

4. Polizzi G, Grunder U, Goené R, Hatano N, Henry P, Jackson WJ, et al: Immediate and delayed implant placement into extraction sockets: A 5-year report. Clin Implant Dent Relat Res. 2000; 2 (2): 93-99. https://doi.org/10.1111/j.1708-8208.2000.tb00111.x

5. Cochran DL, Morton D, Weber HP: Consensus statements and recommended clinical procedures regarding loading protocols for endosseous dental implants. Int J Oral Maxillofac Implants. 2004; 19 (suppl): 109-113.

6. Chee WW, Donovan TE: Treatment planning and soft tissue management for optimal implant aesthetics. Ann Acad Med Singapore. 1995; 24 (1): 113-117.

7. Su H, Gonzalez-Martin O, Weisgold A, Lee E: Considerations of implant abutment and crown contour: critical contour and subcritical contour. Int J Periodontics Restorative Dent. 2010; 30 (4): 335-343.

8. Bishti, S., J. R. Strub and W. Att: Effect of the implant-abutment interface on peri-implant tissues: a systematic review. Acta Od ontol Scand. 2014; 72 (1): 13-25. https://doi.org/10.3109/00016357 .2013 .799712

9. Steigmann M, Monje A, Chan HL, Wang HL: Emergence profile design based on implant position in the esthetic zone. Int $\mathrm{J}$ Periodontics Restorative Dent. 2014; 34 (4): 559-563. https://doi.org/ 10.11607/prd.2016

10. Hensten-Pettersen A. Skin and mucosal reactions associated with dental materials. Eur J Oral Sci. 1998; 106 (2 Pt 2): 707-712.

11. Munksgaard EC, Peutzfeldt A, Asmussen E: Elution of Tegdia and BisGMA from a resin and a resin composite cured with halogen or plasma light. Eur J Oral Sci. 2000; 108 (4): 341-345. https://doi.org/10.1034/j.1600-0722.2000.108004341.x

12. Kan J, Roe P, Runcharassaeng K, Patel R, Waki T, Lozada J, ZimMERMAN G: Classification of Sagittal Root Position in Relation to the Anterior Maxillary Osseous Housing for Immediate Implant Placement: A Cone Beam Computed Tomography Study. The International journal of oral \& maxillofacial implants. 2011; 26. 873-876.

13. KoIs JC: Predictable single-tooth peri-implant esthetics: five diagnostic keys. Compend Contin Educ Dent. 2004 Nov; 25 (11): 895-896., 898., 900.

14. Esposito M, Grusovin MG, Coulthard P, Worthington HV: Different loading strategies of dental implants: a Cochrane systematic review of randomised controlled clinical trials. Eur J Oral Implantol. 2008 Winter; 1 (4): 259-276. Review.

15. HinDs KF: Custom impression coping for an exact registra-tion of the healed tissue in the esthetic implant restoration. Int $J$ Periodont Rest Dent. 1997; 17: 585-591. 
BerkeI G, LUKÁCS L, VÁG J

Immediate implantation and soft-tissue preservation with PMMA temporary abutment combined with the extracted tooth

Case report

Background: Nowadays, there is an increased demand for aesthetic restorations with healthy peri-implant soft tissue. Immediate implantation and temporization could facilitate the preservation of the original soft tissue architecture. A possible scenario could be the application of PMMA (poli metil-metacrilate) temporary abutments with proper contour of the peri-implant mucosal surface.

Description: A 30-year-old female patient visited the dental office. The level of the mucosa and the papilla next to the broken tooth harmonized with the adjacent teeth and soft tissues. The treatment plan aimed to preserve the current soft tissue conditions. A bone level implant (Bone Level Tapered SLActive, Straumann) was placed immediately after the extraction with xenograft bone substitute material (Botiss, Cerabone) to promote the preservation of the bone architecture. Screw-retained temporary crown in infraocclusion was immediately placed on the implant. The temporary crown was fabricated by bonding the extracted tooth to a modified PMMA temporary abutment. After the maturation of the peri-implant mucosa and complete integration of the implant, an open tray A-silicon impression was taken by a customized impression coping. The emergence profile of the temporary crown was replicated by pattern resin-modified impression coping. The final restoration was a cementable e.max crown seated on a customized zirconia dioxide abutment. The zirconia dioxide abutment was cemented to its titanium variobase and it resembled the shape of the temporary abutment and seated perfectly into the emergence profile.

Keywords: PMMA temporary abutment combined with the original tooth could be an effective method to fabricate a chairside temporary crown.

\section{Hírek \\ News}

\section{Állami kitüntetések}

Magyarország köztársasági elnöke a nemzeti ünnep, március 15-e alkalmából kitüntetéseket adományozott.

Példaértékű orvosi, tudományos és oktatói pályafutása során a szájüregi betegségek gyógyítása, valamint a szakmai utánpótlás képzése terén elért eredményei elismeréseként dr. Olasz Lajos, a Magyar Tudományos Akadémia doktora, a Pécsi Tudományegyetem professor emeritusa részére a Magyar Érdemrend tisztikeresztje polgári tagozata kitüntetést adományozta.
A hazai graduális, illetve posztgraduális fogorvosképzés területén végzett munkája, valamint szakmai közéleti és érdekképviseleti szerepvállalása elismeréseként Magyar Érdemrend Lovagkeresztje polgári tagozat kitüntetést kapott dr. Gerle János, a Fogorvostudományi Kar Oktatási Centrumának igazgatója, valamint dr. Hermann Péter, a Semmelweis Egyetem oktatási rektorhelyettese, a Fogorvostudományi Kar Fogpótlástani Klinikájának igazgatója. Több évtizedes kutató-, oktató- és gyógyító munkája, valamint a hazai fogorvostudományi képzés szervezésében és fejlesztésében vállalt szerepe elismeréseként részesült a dijjban.

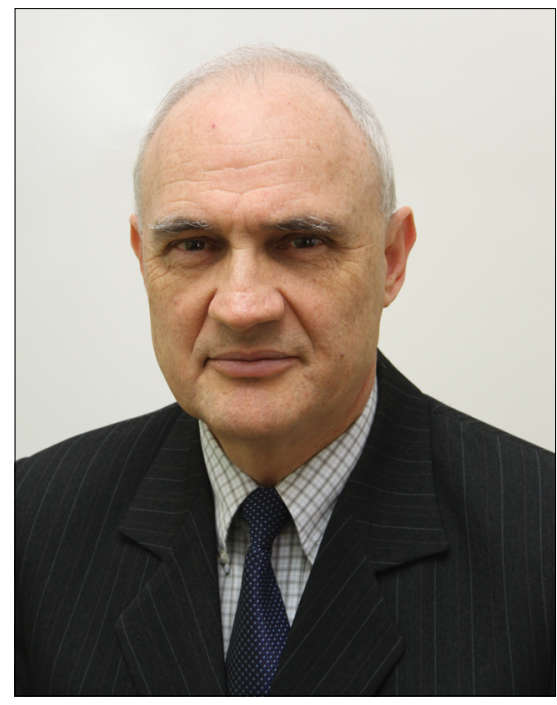

dr. Olasz Lajos

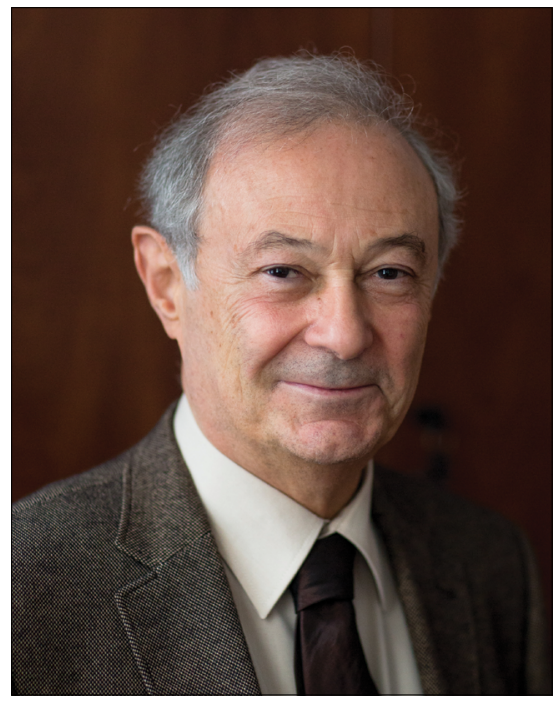

dr. Gerle János

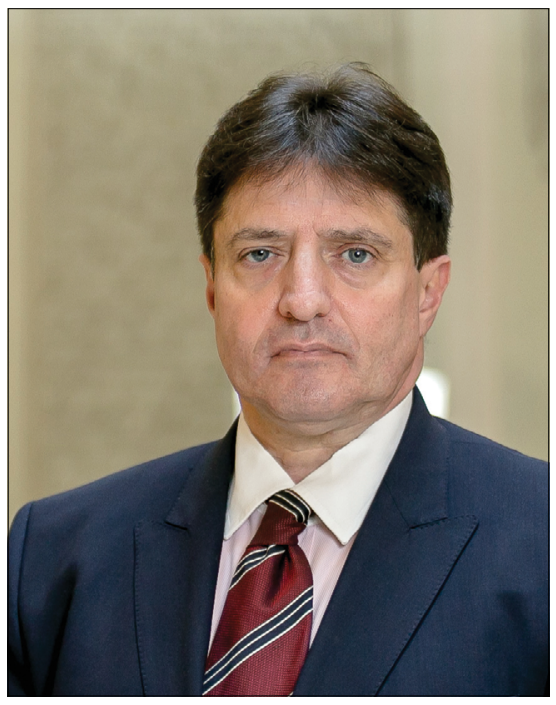

dr. Hermann Péter 